\title{
ANALYSIS OF HOST PREFERENCE AND RELATIONSHIP OF APHID SPECIES AND THEIR PARASITOIDS IN WHEAT FIELDS AND SURROUNDING AREAS, IN DIYARBAKIR AND ŞANLIURFA PROVINCES, TURKEY
}

\author{
BAYRAM, Y. \\ Ministry of Agriculture and Forestry, General Directorate of Food and Control, 06110 Ankara, \\ Turkey \\ (e-mail: yunusb04@yahoo.com)
}

(Received 22 $2^{\text {nd }}$ May 2020; accepted $14^{\text {th }}$ Sep 2020)

\begin{abstract}
This study was carried out to investigate the relationship and host preference of aphids and their parasitoids on different host plants in Diyarbakır and Şanlıurfa provinces in 2014-2015. In this study, 24 aphid species belonging to 18 genera, 10 parasitoid species belonging to 6 genera and 20 plant species belonging to 8 families were evaluated. Biodiversity Pro V7 package program was used for diversity cluster analysis and to determine similarity between host plant species, aphids and their parasitoids. Lysiphlebus fabarum (Marshall) and Praon volucre (Haliday) were observed as the most active parasitoids, with preference of five different aphid species, while the remaining aphid species were parasitized by the other parasitoid species. However, Aphelinus paramali (Zehavi \& Rosen) was found to be specifically parasitizing only one aphid species. The highly parasitism percentage of 10 parasitoid species over 24 different aphid species and their complex relationship in wheat fields and surrounding areas, provided a wonderful natural balanced of biodiversity and possibility to control of aphids in Southeast Anatolia Region. The results of this study will provide useful knowledge in order to introduce biological control possibilities under the framework of integrated pest management.
\end{abstract}

Keywords: crops, weeds, diversity, aphids, natural enemies, parasitism, biological control, IPM

\section{Introduction}

Winter wheat, (Triticum aestivum L.) is main crop in Turkey and constitutes $3.5 \%$ of the world wheat area (Anonymous, 2018a). This area also accounts for $20 \%$ of total cultivated farmland in Turkey (Anonymous, 2018b).

Aphids among other insects are the main pests causing the highest damage to wheat production at approximately 30\% yield loss per year (Webster and Kenkel, 1999). There are nearly 4,400 aphid species belonging to 599 genera in the Aphidomorpha (Hemiptera) superfamily in the world, 3,706 species of which live in the Palearctic region (Remaudière et al., 2006; Blackman and Eastop, 2020; Favret, 2020). Many studies have been conducted to determine the number of aphid species in Turkey and according to these studies, 558 aphid species belonging to 8 subfamilies of Aphidoidea were determined in Turkey (Düzgüneş et al., 1982; Görür et al., 2012; Şenol et al., 2014; Kök et al., 2016; Akyürek et al., 2019; Özdemir, 2020).

The locomotive sector of the Southeast Anatolia Region is agriculture. 3.2 million ha of 7.5 million ha area in the region is suitable for agricultural activities. Currently, 93.6\% of red lentils, $96.3 \%$ of pistachios and $35.3 \%$ of wheat, are supplied from this region (Anonymous, 2020). Various studies related to aphids and natural enemies on wheat have also been carried out in this region (Bodenheimer and Swirski, 1957; Tuatay and Remaudiere, 1964; Tuatay, 1988; Kıran, 1994; Elmalı and Toros, 1994; Ölmez, 2000; Yüksel, 2003; Şimşek et al., 2005; Remaudiere et al., 2006; Ölmez Bayhan et al., 2012, 2013; Aslan, 2013; Bayram and Bayhan, 2013, 2016; Bayram et al., 2018). 
Aphids are able to transmit plant viruses directly or indirectly from secondary host plants to main crops (Kennedy et al., 1962). Therefore, it should be well known to understand the presence secondary host plants such as early growing plants, weeds or uncultivated plants as much as main crops for estimating aphid damage and their ability by carrying viruses from one plant to another (Bayram et al., 2018).

Aphid species generally live on their host plant species in colonies. Aphids change their host plants as facultative or obligate and this change includes two (dioeciously species) or more (heteroecious species) host plants. Although there is no clear relationship between main crops and secondary host plants, there is a clear explanation that main crops and secondary host plant species are classified under the same genus and the same families (Kristoffersen, 2003). Host preferences of aphid individuals are affected by numerous factors such as the structure of plant surface, as well as plant color and odor. Some specific substances such as phenols, alkaloids and oils affect aphid feeding and host plant preference (Özdemir, 2013).

As it is difficult to control aphids and chemical control is not a sustainable or environmentally friendly method, studies generally have been focused on alternative control strategies such as biological control, biotechnical control and cultural measures. There are many studies about aphid parasitoids (Kıran, 1994; Ölmez, 2000; Kavallieratos and Lykouressis, 2000; Kavallieratos et al., 2001; Praslićka et al., 2003; Legrand et al., 2004; Aslan, 2013; Bayram and Bayhan, 2013, 2016; Bayram et al., 2018). Investigation on host preference and relationship between aphids and parasitoids is one of the most important points for establishing a comprehensive control strategy. Therefore, this study was carried out to investigate host preference and relationship of aphids and parasitoids on wheat and neighboring habitats.

\section{Materials and Methods}

\section{Field studies}

Studies were carried out in wheat growing areas and neighboring habitats randomly, from different fields in 2014 and 2015 in Diyarbakır (Yenişehir and Kayapınar central counties) and Şanlıurfa (Akçakale, Siverek counties) provinces (Figure 1). Aphid colonies consisting of both live and mummified aphids were collected together with their host plants. Field studies were conducted during April, May and June by examining and sampling shoots, plants, leaves, branches and trunk of each plant once a week, while in November and February months by sampling once a month, with irregular controlling of 70 different locations. Each sample was placed in a plastic container and brought to the laboratory for rearing.

\section{Laboratory studies}

Studies were established under controlled conditions $\left(25 \pm 3^{\circ} \mathrm{C}, 70 \% \pm 10 \% \mathrm{RH}\right.$ and 16:8 L:D) in climatic rooms. Samples were examined daily for emerged aphids and parasitoids. Both adult aphids and parasitoids were preserved in $70 \%$ ethanol for subsequent identification. The slide mounting technique was mainly based on the method of Hille Ris Lambers (1950). The specimens were studied using a LEICA DM LB2 compound light microscope and morphological characters were measured using LAS 4.1 version software. Measurements of morphological characters were made according to Blackman and Eastop (2020). 


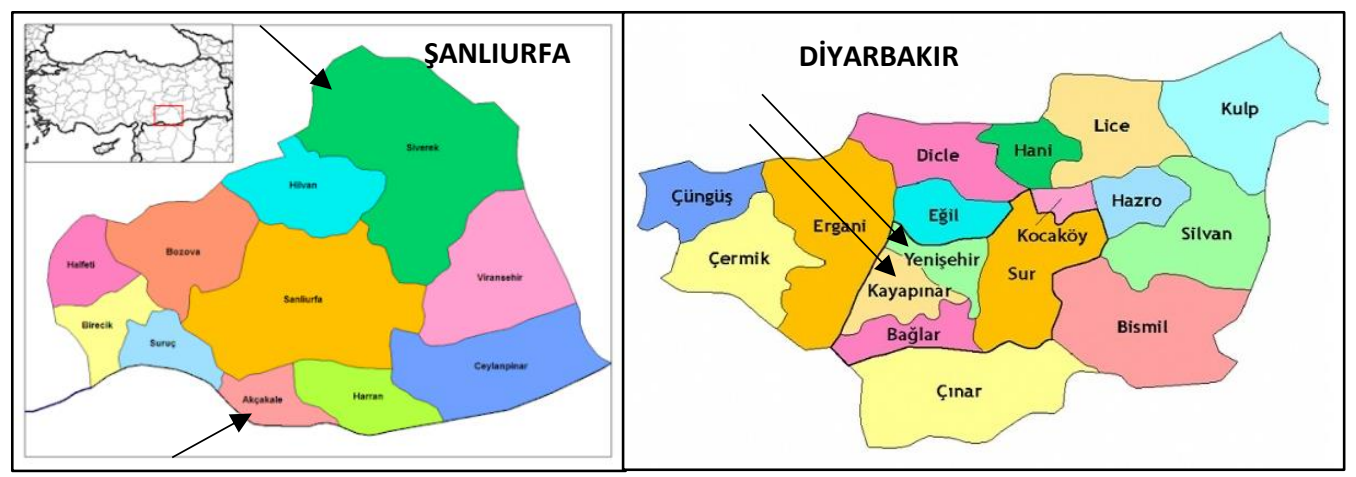

Figure 1. Map of Diyarbaklr and Şanluurfa provinces in which field studies were carried out

\section{Host plant species}

Wheat fields and the nearest area around these fields were examined carefully and plant samples were taken together with mummified aphids to laboratory for identification. Secondary host plants such as uncultivated plants and weeds around wheat fields were identified by Prof. Dr. Bekir BÜKÜN (Dicle University, Faculty of Agriculture, Plant protection Division) and Erdal ATEŞ (Plant Protection Research Institute, Diyarbakır). Identification studies of host plants, aphids and their parasitoids were published by Bayram et al. (2018).

\section{Preparation and identification of aphids and parasitoid specimens}

Aphids and parasitoids were examined and separated under a binocular and were placed into small bottles or tubes with $70 \%$ alcohol. The tubes and bottles with aphids and parasitoids were recorded with required information and prepared for identification. The colors of aphid mummies were also recorded, considering that they could be useful for identification and classification. Selected fresh specimens of aphids were immersed in $75 \%$ ethanol and preserved for future identification. Adult parasitoids were preserved in $96 \%$ ethanol. Some specimens were mounted on slides. Aphids were removed from their host plant with a small soft brush and put into a tube which contained $70 \%$ alcohol. The preservation techniques were mainly based on the method of Hille Ris Lambers (1950). The morphological terminology used as key for parasitoid species identification was based on (Sharkey and Wharton, 1997; Kavallieratos and Lykouressis, 2000; Kavallieratos et al., 2001) literatures. Aphid species were identified by specialist Dr. Iş11 Özdemir (Central Plant Protection Research Institute, Ankara). Parasitoid species were identified by specialist Zeljko Tomanoviç (University of Belgrade, Faculty of Biology, Serbia).

\section{Cluster analysis of host plants, aphids and parasitoids}

Jaccard similarity index (Magurran, 2004) was used for determining the faunal similarity of host plant families from which aphids were obtained and Biodiversity Pro V7 package program (Biodiversity Pro. 1997), which is a statistical package program for Windows PC, enabling many measures of diversity to be calculated for a dataset of taxa by samples, was used for determining cluster analysis of aphid similarity from which parasitoids were obtained. 


\section{Determination of the amount of emerging parasitoid individuals and parasitized aphid species}

Mummified aphids and plant samples were collected from different locations randomly. These samples were recorded and each of the samples was separated in the laboratory. Plant materials with mummified aphids were taken into plastic boxes and required information was recorded on the boxes. The cover of the plastic boxes was cut as widely round and closed with tight textured nylon muslin to provide ventilation. The samples were kept for at least 14 days and controlled daily until parasitoid adult emerged. Each sample was followed separately and parasitoid exit recorded according to parasitoid and aphid species. The obtained data determined the total number of parasitoid exit for each aphid species and the number of aphid species parasitized by the same parasitoid species.

\section{Results and Discussion}

The cluster similarity analysis of main crops (wheat) and surrounding host plants and uncultivated plants in terms of hosting aphids was shown on Figure 2. Alopecurus myosuroides Hudson, Carduus crispus L., Cirsium vulgare (Savi) Airy-Shaw., Daucus carota L. var. carota, Galium aparine L., Orobanche sp. and Sonchus oleraceus L., host plants were determined as specific host plants for obtaining aphid species. However, other host plant species such as; Amaranthus retroflexus L., Avena fatua L., A. sterilis L., Centaurea solstitialis L., Lolium perenne L., Onopordum acanthium L., Papaver rhoeas L., Silybum marianum (L.) Gaertn, Triticum aestivum L. Emd., T. durum Desf., and Vicia sativa L., were determined as unspecific host plants for obtained aphid species and these aphid species could feed on other host plants at a certain rate. Lens culinaris Medicus and Lupinus albus L., plant species hosted the same aphid species (Figure 2).

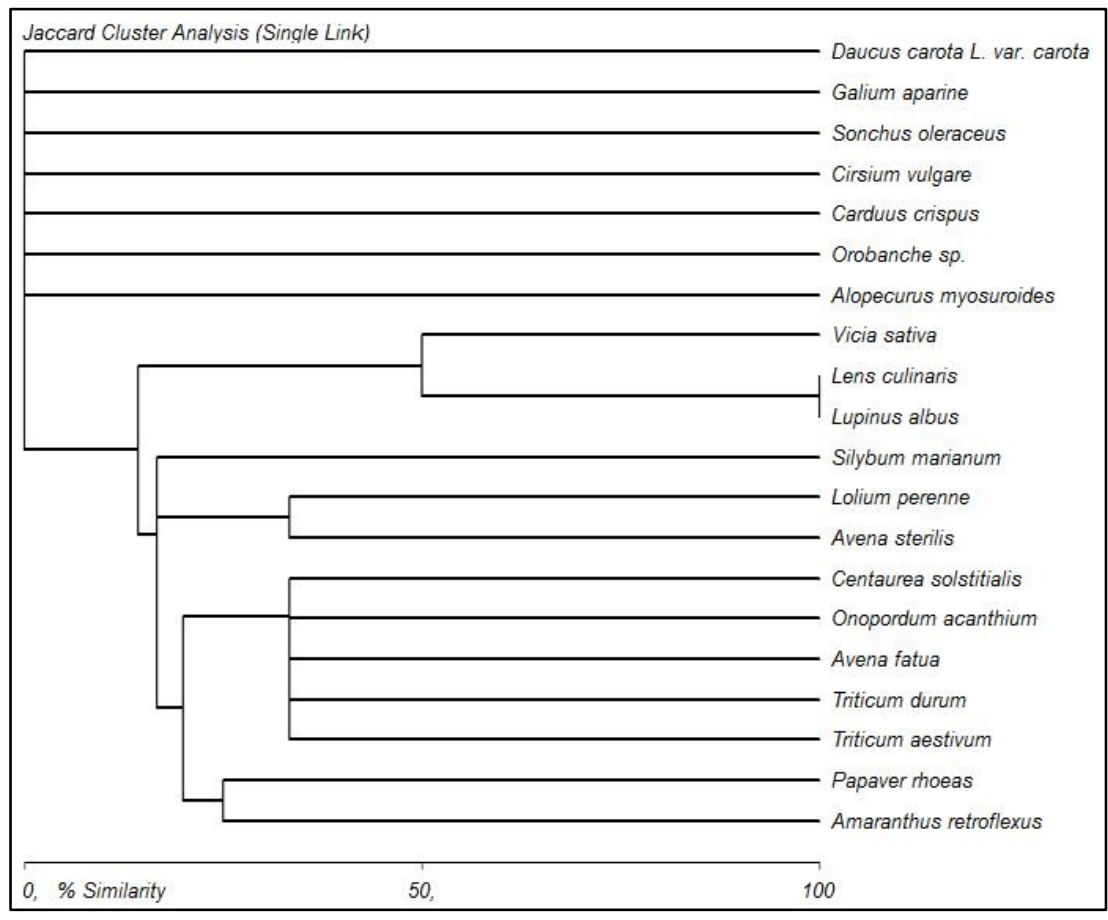

Figure 2. Similarity of cereals and uncultivated plant species in terms of hosting aphid species 
The cluster similarity analysis of aphids in terms of host plant preference was shown on Figure 3. Aphis gossypii Glover, A. galiiscabri Schrank, Diuraphis noxia (Kurdjumov), Dysaphis foeniculus (Theobald), Hyperomyzus lactucae (L.), Smynthurodes betae Westwood and Uroleucon (Uromelan) jaceae (L.) aphid species fed on certain host plant groups and those host plant species weren't preferred by the other aphid species. Uroleucon cichorii (Koch) and Capitophorus elaeagni (deI Guercio) aphid species preferred the same host plant. However, the other aphid species could tend to prefer the same host plant species in different rates. The percentage of similarity of host plant preference of Anoecia corni (Fabricius), Aphis fabae Scopoli, Aulacorthum solani (Kaltenbach), Lipaphis erysimi (Kaltenbach), Macrosiphum euphorbiae (Thomas), Metopolophium dirhodum (Walker), Myzus (Nectarosiphon) persicae (Sulzer), Sipha (Rungsia) maydis Passenger, and Uroleucon sp., was 50\%. The percentage of similarity of host plant preference for other aphid species such as; Aphis craccivora Koch, Brachycaudus (Acaudus) cardui (L.), B. helichrysi (Kaltenbach), Rhopalosiphum maidis (Fitch), R. padi (L.) and Sitobion avenae (Fabricus) was less than 50\% (Figure 3).

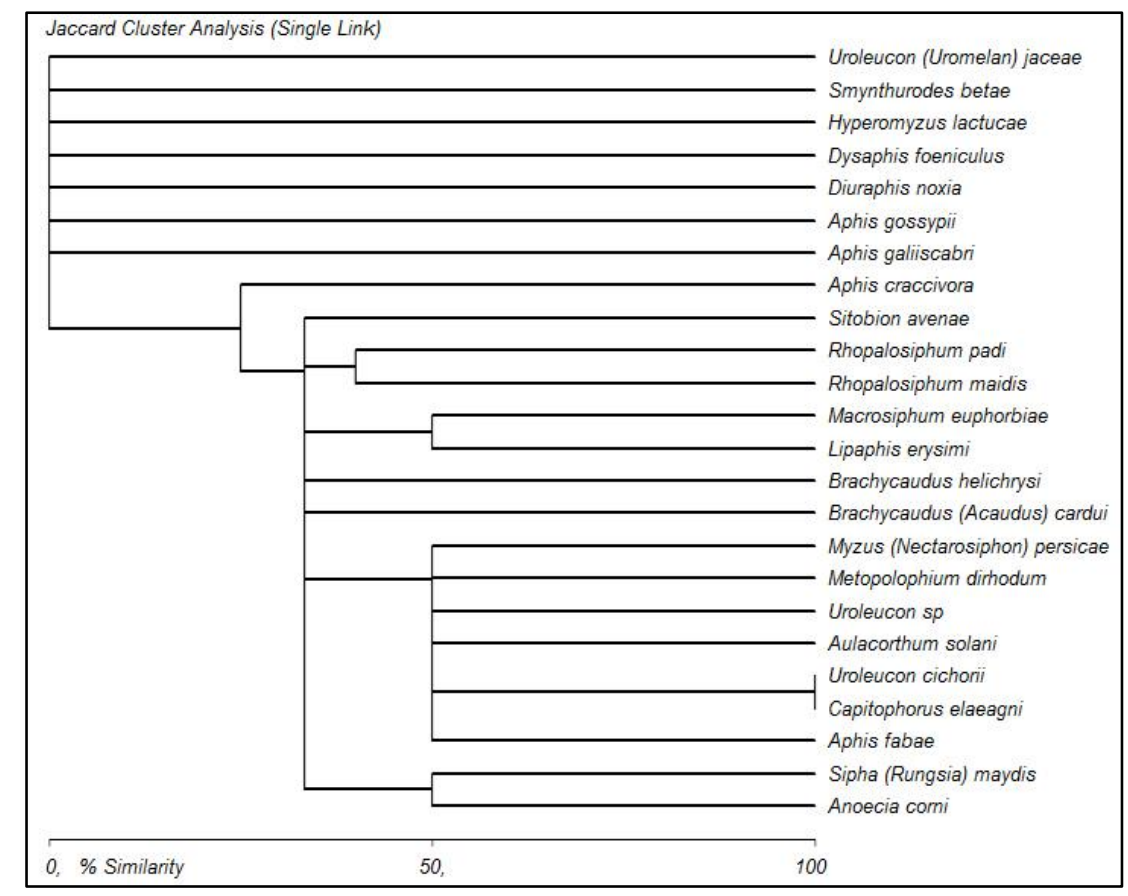

Figure 3. Similarity of aphid species in terms of host plant preferences

The cluster similarity analysis of parasitoids in terms of aphid preference was shown on Figure 4. Parasitoid species that parasitizing Rhopalosiphum maidis, Hyperomyzus lactucae, Brachycaudus helichrysi and Aphis gossypii aphid species were tending to prefer only one aphid species. However, the other parasitoid species could tend to prefer different aphid species at a certain rate. Lipaphis erysimi, Diuraphis noxia and Aulacorthum solani aphid species were parasitized by the same parasitoid. Uroleucon cichorii, U. (Uromelan) jaceae, Rhopalosiphum padi, Macrosiphum euphorbiae and Aphis galiiscabri aphid species were parasitized by one parasitoid (Praon volucre Haliday). Myzus (Nectarosiphon) persicae and Dysaphis foeniculus were parasitized by the same parasitoid (Lysiphlebus fabarum). Brachycaudus (Acaudus) cardui, Aphis fabae, 
and A. craccivora, aphid species were also parasitized by the same common parasitoid species (Figure 4).

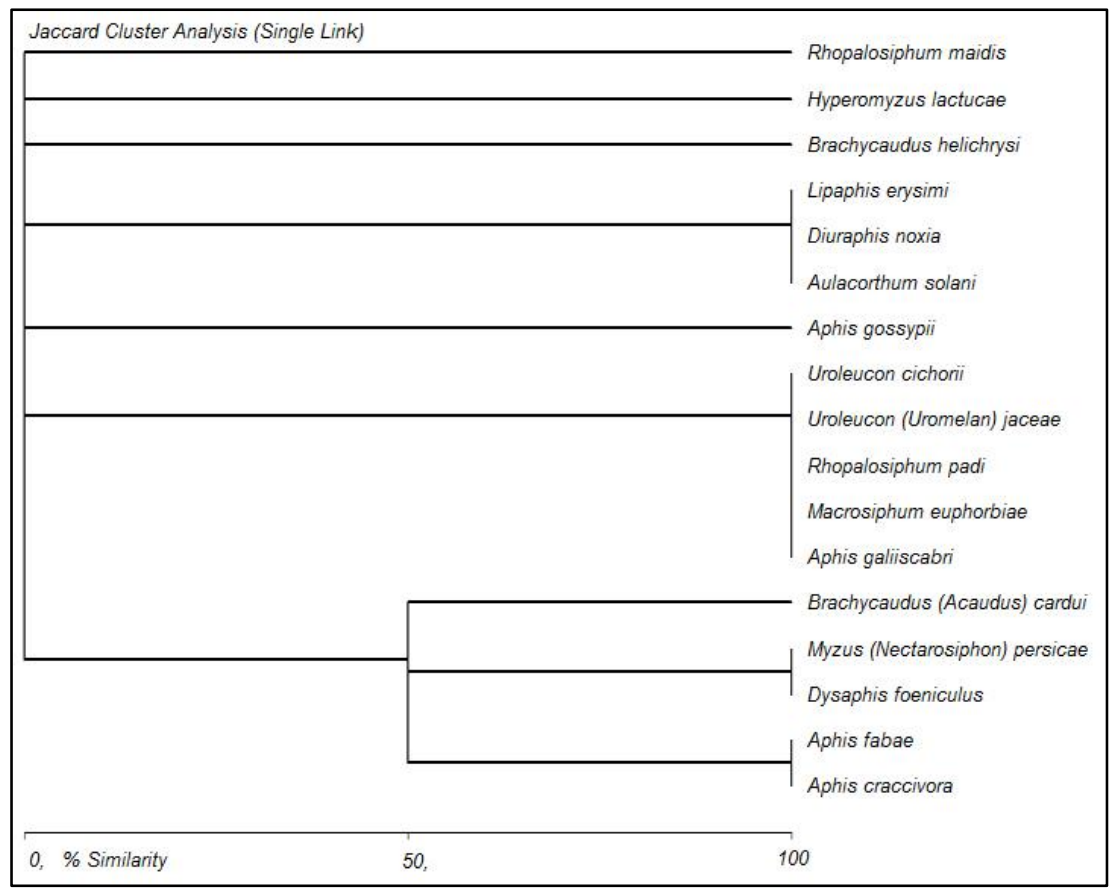

Figure 4. Similarity of parasitoid species on aphid species

The cluster similarity analysis of parasitoid species and the number of emerging parasitoid individuals and parasitized aphid species were shown on Figure 5 and Figure 6. It was observed that certain parasitoid species such as Praon volucre, Diaeretiella rapae (M'Intosh), Aphidius rhopalosiphi de Stefani-Perez, Aphidius matricariae Haliday and Aphidius colemani Viereck were specialized on certain aphid species. Binodoxys acalephae (Marshall), Lysiphlebus fabarum (Marshall) and Aphidius ervi Haliday tended to prefer common aphid species. The other parasitoid species Lysiphlebus testaceipes (Cresson) and Aphelinus paramali Zehavi \& Rosen were parasitizing the same aphid species (Figure 5). It was revealed that L. fabarum is parasitizing Brachycaudus (Acaudus) cardui; Praon volucre is parasitizing Uroleucon cichorii, U. (Uromelan) jaceae, Rhopalosiphum padi, Macrosiphum euphorbiae and Aphis galiiscabri; Aphidius ervi is parasitizing Myzus (Nectarosiphon) persicae; Aphidius rhopalosiphi is parasitizing Rhopalosiphum maidis; Aphidius matricariae is parasitizing Brachycaudus helichrysi; Lysiphlebus testaceipes; and Aphelinus paramali is parasitizing Aphis gossypii; and Diaeretiella rapae is parasitizing Diuraphis noxia (Figure 5).

Praon volucre was found the most effective parasitoid both in terms of obtaining parasitoid individuals (147 individuals) and having the ability of parasitizing 5 different aphid species. Lysiphlebus fabarum also has a high parasitizing tendency towards many different aphid species ( 5 species) and it has a high parasitizing capacity (110 individuals) (Figure 6). Although those five aphid species were parasitized by the other parasitoid species (Binodoxis acalephae, Aphidius ervi), Lysiphlebus fabarum has a high parasitizing capacity and tendency of so many different aphid species including ability of highly competitive. Diaeretiella rapae parasitized three different aphid species, while 


$$
-6933-
$$

Aphidius rhopalosiphi parasitized two different aphid species. Aphidius ervi, A. colemani, A. matricariae, Aphelinus paramali and Lysiphlebus testaceipes parasitoid species were obtained only from one separate aphid species (Figure 6).

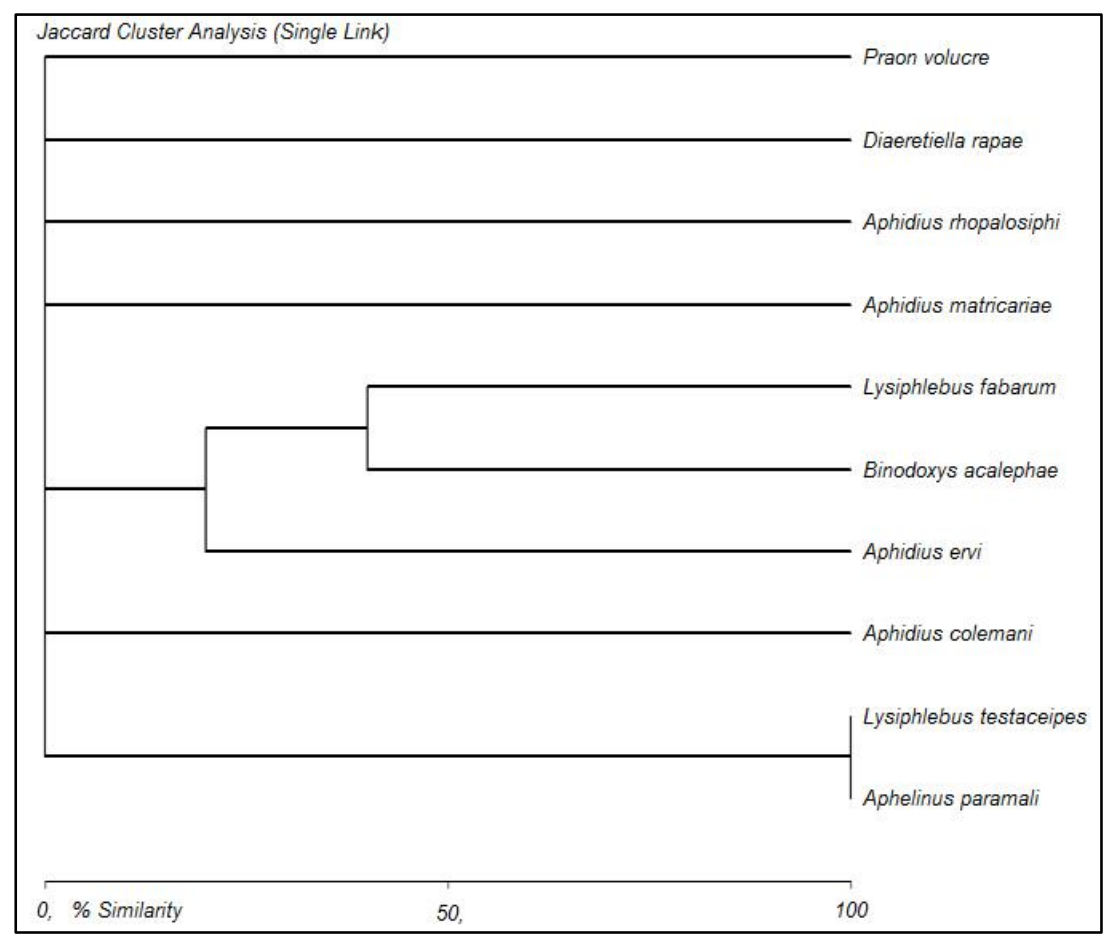

Figure 5. Similarity of parasitoid species in terms of aphid preferences

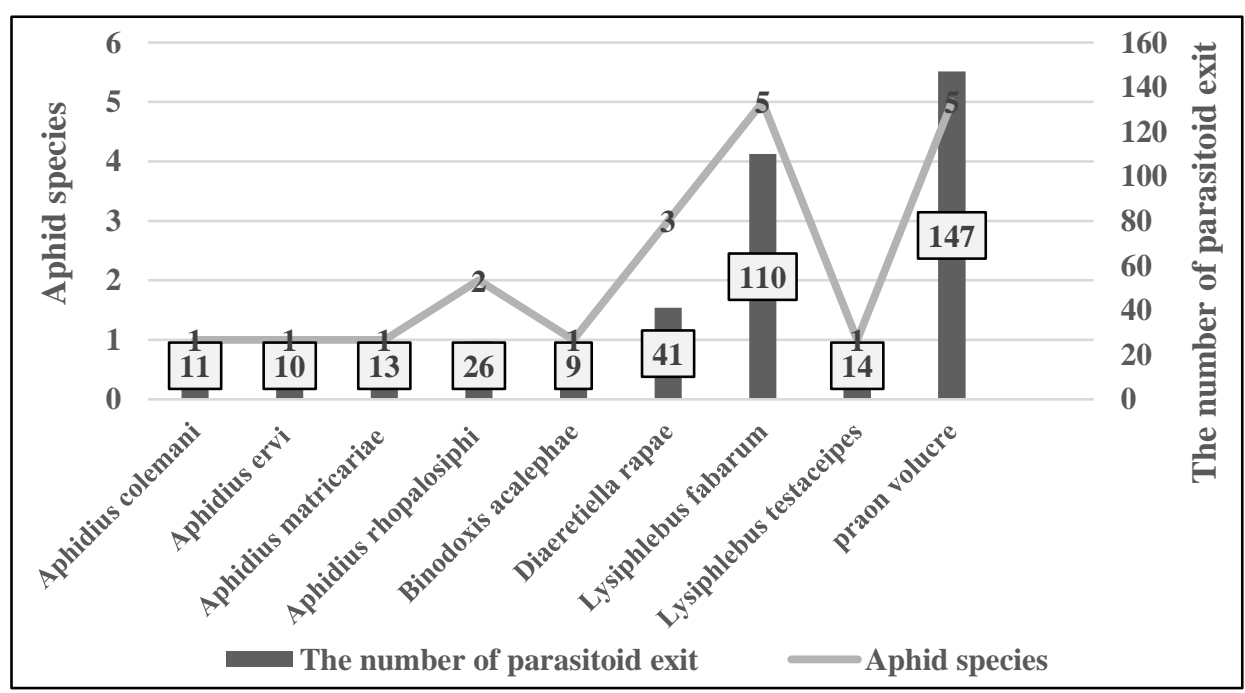

Figure 6. The number of emerged parasitoid individuals and the number of aphid species parasitized by the same parasitoids

According to former studies conducted in the world related to host plants, aphids and their parasitoids; Nine aphid species [D. noxia, M. dirhodum, $R$. maidis, $R$. padi, $S$. graminum Rond., Sitobion avenae, S. fragariae (Walker), Sipha elegans del Guercio and 
S. maydis] were determined in wheat fields of Yugoslavia (Petrović, 1996). In Southeastern Europe 422 host plant species, 208 aphid species and 122 parasitoid species, 115 of which belonged to Aphidiinae genus were identified and 561 parasitoid-aphid relations were described (Kavallieratos et al., 2004). The relationship of $S$. avenae and Aphidius rhopalosiphi in spring, autumn and winter months in Belgium revealed that the fields where the parasitoid were available, the aphid population decreased rapidly and lasted at a low level (Legrand et al., 2004). Four aphid parasitoid species belonging to Aphidiidae family in the Angola region were determined. While D. rapae and Ephedrus persicae Froggatt parasitoid species were determined as cosmopolitan species. Aphidius platensis Brethes was obtained from some domestic aphids or some materials that collected from out and A. camerunensis Mack was only determined on some Sitobion species (Stary and Van Harten, 1972). The most dominant aphid species were Aphis fabae and Cirsii acanthoidis Börner, while the most related parasitoids were L. cardui (Marshall), and L. fabarum on Cirsium arvense (L.) in Czechoslovakia (Stary, 1986). Four parasitoid species (A. ervi, A. eadyi StarýFebGonzález \& Hall, A. picipes (Nees) and $P$. barbatum Mackauer) were found on pea aphid in Yugoslavia, and A. ervi was found as the most dominant species (Tomanović et al., 1996). Eight new aphid species with their host plants, including 12 Aphidiinae parasitoids, four of which new record was reported in Serbia and Montenegro (Tomanović, 2000). A. ervi, A. uzbekistanicus Luzhetzki, A. rhopalosiphi and $P$. gallicum Starý were found as the most intense parasitoid species in the wheat fields of Southern agro-eco systems of the Pannonia region (Tomanović and Brajkovic, 2000). A new aphid parasitoid species Praon uroleucon Tomanović \& Kavallieratos, identified in Yugoslavia, and this parasitoid species parasitize Uroleucon aphid species on Carduus acanthoides L., host plant (Tomanović et al., 2003). Seven aphid parasitoid species (Aphidius uzbekistanicus, A. ervi, A. picipes, A. rhopalosiphi, Ephedrus plagiator Nees, Praon volucre and P. gallicum) were determined in wheat fields of Slovakia (Praslićka et al., 2003).

Aphid parasitoids generally hibernate in diapause in winter as prepupae in mummified aphids in the regions where the temperature is mild (climate, weather). By the migration of aphids from one host to another host plant habitat with summer or in the warmer season conditions, seasonal diapause of parasitoids also could be observed (Minks and Harrewijn, 1988). Stary (1964) reported that the relation between dioecious aphids and their parasitoid is even more complex. These aphid species always change their habitats throughout the season from primary host plants to secondary host plants due to their migration behavior. Therefore, their parasitoids habitat also changes throughout the season depending on the migration of aphids. In this case, any dioecious aphid could be parasitized by different parasitoid species complex according to its habitat type. For example, Brachycaudus cardui aphid species could be found on the edges of wooded areas and in the parks on Prunus spinosa L., and P. domestica L. host plants in spring or in winter and parasitized by Ephedrus plagiator, while this species migrates towards the end of spring or at the beginning of summer on weeds such as Carduus sp. and Arctium sp., and parasitized by Lysiphlebus fabarum and Lipolexis gracilis Forster. However, Monoecious aphids even if migrating to other plants for feeding purposes, they do not change their habitat types throughout the season. Therefore, studies revealed that these aphid species generally parasitized by the same parasitoid species.

According to the former studies conducted in Turkey about host plants, aphids and their parasitoids; 13 aphid species, 5 parasitoid species and 21 predator species were determined in the wheat fields of Konya province (Elmal1, 1993). 10 aphid parasitoids 
belonging to 6 genera were determined on weeds areas of Ankara province (Güz and Kilınçer, 2005).

According to the former studies conducted in Southeastern Anatolia Region, five aphid species Sitobion avenae, Rhopalosiphum padi, R. maidis, Schizaphis graminum and Myzus persicae and two parasitoid species Lysiflebus faborum and Ephedrus plagiator were determined in the wheat fields of Southeastern Anatolia Region (Kıran, 1994). In addition, 24 aphid species belonging to 18 genera, 10 parasitoid species belonging to 6 genera were determined in wheat and surrounded areas on 20 host plants belonging to 8 families in Southeastern Anatolia Region (Bayram et al., 2018).

By this study, the cluster analysis of similarities and differences of host plants, aphids and parasitoids was evaluated. Since there are many host plant samples, aphids and parasitoid species, it is hard to exactly differ their relation with each other, or to evaluate each element separately. While some aphid species preferred one host plant species, the other aphid species preferred more host plant species and two or more aphid species could be seen over the same host plant species as well.

The aphid species are generally a significant food source both for parasitoids and predator. While some aphid parasitoids which are so specific and representing the isolated complexes have no relation in the food chain, the other aphid parasitoids have a more complex relationship. Lysiphlebus fabarum and Praon volucre were found very active having both abilities of parasitizing five different aphid species and reproductive capacity. However, Aphelinus paramali was found specified only one aphid species. The difference of the host plant change or the presence of main crops and uncultivated host plant species, in connection with aphid host series determine the composition of parasitoid species and their percentage into this composition. The parasitizing activity of 10 parasitoid species over 24 different aphid species and their complex relationship with the highly parasitizing rate is a wonderful natural balance in wheat fields and surrounded areas of Southeastern Anatolia Region (Bayram et al., 2018). Sometimes main crops are not available in the environment, so the presence of uncultivated plants or weeds around the main crops is a good opportunity for reproduction of first generations of aphid colonies on these host plants and also an integrative element for first generation of parasitoids which is emerging at the beginning of spring and lying eggs to aphid colonies. The richness of biodiversity guarantees the sustainability of not only the aphid living, but also the beneficial insects living. Although Monoecious aphids migrate to other plants for feeding purposes, they do not change their habitat types throughout the season, so Monoecious aphids are generally parasitized by the same parasitoid species.

The same as harmful organisms, beneficial insects also could not survive in the pesticide used areas. However, the environment that has not been treated with pesticides such as weeds or uncultivated areas are suitable both for pests and for beneficial insects to survive. These areas are good reservoirs and provide a perfect biodiversity. The reason for numerous cereal aphid species kept below the threshold of economic damage depends on these herbaceous plants in the vicinity of grain fields. The relationship of aphids and their parasitoids depend on vegetation diversity of the same or different areas. The availability of these flowering weeds before the vegetables, cottons or other cultivated crops planted in early spring, provides an opportunity for parasitoids to feed on these flowering weeds together with aphids and then migrate to other cultivated areas (Bayram et al., 2018). 


\section{Conclusion}

This study has aimed to investigate the host preference and relationship between aphids and their parasitoids on different host plants growing on wheat fields and surrounding areas in Turkey, in order to help develop biological control methods.

Although chemical control is primary resort for pest control in main crops, uncultivated plants, or weeds around main crops are not treated with chemicals, so these plants are reserving so many pests and beneficial insects as well. In Southeastern Anatolia Region wheat production is getting mature at the beginning of summer, so aphids could give damage to only some local points with some limited colonies which are formed at the edge of the fields. Except for any extra situation there is no needs for chemical control. Producers also do not use chemicals for aphid control in wheat fields, and the use of some chemicals against Sunnpest suppresses aphid population as well.

The presence of many aphid species, the richness of parasitoid species and their effectiveness, tendency and complex relationship over many aphid species in main crops, and uncultivated host plants and weeds are valuable and helpful resources for suppressing aphid population by using these beneficial insects. The survival of these parasitoids is useful not only for the wheat production, but also for suppressing the aphid populations in other secondary products. This resource should be well protected by avoiding unnecessary pesticide usage and by educating growers for increasing their awareness about the importance of beneficial insects. The analysis of interaction of host plants, similarities and differences among host plants, aphids and parasitoids, and determining the most active and common parasitoid species will be a useful knowledge in the framework of biological control and integrated pest management.

Future studies should focus on the protection as well as the production, reproduction, preservation of these beneficial insects and their transition to secondary host plants following wheat main crop. The possibilities of using these beneficial insects for controlling aphid species in corn, vegetables, fruits and industrial plants which are cultivated in the summer should be investigated. Opportunities should be sought to preserve this natural enemy in the Southeastern Anatolia Region, to survive and to benefit throughout the year. Usually weeds are not liked, whereas it should be taken into consideration that these weeds are a good habitat for beneficial insects to survive, and these plants that grow by themselves around wheat fields should not be destroyed.

Acknowledgements. I am thankful to Dr. Mustafa ÖZDEMİR (Central Plant Protection Research Institute, Ankara) for his contribution about using biodiversity program and analysis.

\section{REFERENCES}

[1] Akyürek, B., Zeybekoğlu, Ü., Görür, G., Karavin, M. (2019): New records for aphid fauna of Turkey from Samsun province. - Munis Entomology \& Zoology 14(2): 383-388.

[2] Anonymous (2018a): USDA. - https://www.usda.gov/oce/commodity/wasde/ (Access date: 01.08 .2020$)$

[3] Anonymous (2018b): TÜİK. - http://www.tuik.gov.tr/PreTablo.do?alt_id=1001 (Access date: 01.08.2020).

[4] Anonymous (2020): http://www.gap.gov.tr/gap-in-hedefleri-sayfa-23.html (Access date: 01.08.2020). 
[5] Aslan, M. (2013): Determination of Aphidoidea (Homoptera) species and their parasitoids and predators in Kahramanmaraş province. - Cukurova University Institute of Science, $\mathrm{PhD}, 136 \mathrm{p}$.

[6] Bayram, Y., Bayhan, E. (2013): Population dynamic of Aphelinus paramali (Zehavi \& Rosen) (Hymenoptera: Aphelinidae) on Aphis gossypii Glover (Hemiptera: Aphididae) feeding on different watermelon varieties. - Turkish Journal of biological control 4(1): 4150 .

[7] Bayram, Y., Bayhan, E. (2016): Life table of Aphelinus paramali Zehavi \& Rosen, 1989 (Hymenoptera: Aphelinidae), a parasite of the melon aphid, Aphis gossypii Glover, 1877 (Hemiptera, Aphididae). - Acta Biologica Turcica 29(4): 111-123.

[8] Bayram, Y., Özdemir, I., Ateş, E., Tomanoviç, Z., Bükün, B., Mutlu, Ç. (2018): Secondary host changing between aphids (Hemiptera: Aphididae) and their parasitoids in wheat fields of Southeast Anatolian Region. - Munis Entomology \& Zoology 13(1): 309-317.

[9] Biodiversity Pro. (1997): http://www.sams.ac.uk/dml/projects/benthic/bdpro (Access date: 12.03.2016).

[10] Blackman, R. L., Eastop, V. F. (2020): Aphids of the world's plants: An online identification and information guide. - Available at http://www.aphidsonworldsplants.info (Access date: 10.7.2020).

[11] Bodenheimer, F. S., Swirski, E. (1957): The Aphidodea of the Middle East. - The Weizmann Science Press of Israel, Jerusalem, 378p.

[12] Düzgüneş, Z., Toros, S., K1lınçer, N., Kovanc1, B. (1982): Detection of Parasites and Predators of Aphidoidea Species in Agriculture and Forestry. - General Directorate of Plant protection and Plant Quarantine, 251p.

[13] Elmal1, M. (1993): Researches on Determination of Aphididae Species and Useful Fauna Damaging in Wheat in Konya Province and Research on Bio ecology of the Most Common Species. - University of Ankara, 156p.

[14] Elmal1, M., Toros, S. (1994): Aphidoidea Species and Occurrence Rates in Wheat in Konya Province. - Ank. Unv. Agriculture Faculty. Publication No: 1454. Scientific Research and Investigations 802: 40.

[15] Favret, C. (2020): Aphid Species File 5.0/5.0. - http://aphid.speciesfile.org. Downloaded on 22 January 2020. (Accessed 22-June-2020).

[16] Görür, G., Akyıldırım, H., Olcabey, G., Akyurek, B. (2012): The aphid fauna of Turkey: An updated checklist. - Arch. Biol. Sci. 64(2): 675-692.

[17] Güz, N., Kılınçer, N. (2005): Aphid parasitoids (Hymenoptera: Braconidae: Aphidiinae) on weeds from Ankara, Turkey. - Phytoparasitica 33(4): 359-366.

[18] Hille Ris Lambers, D. (1950): Host plants and aphid classification. - In proceedings of the $8^{\text {th }}$ International Congress in Entomology, 1948, pp. 141-148, Stockholm.

[19] Kavallieratos, N. G., Lykouressis, D. P. (2000): Two new species of Praon haliday (Hymenoptera: Aphidiidae) from Greece. - Entomologia Hellenica 13: 5-12.

[20] Kavallieratos, N. G., Lykouressis, P., Sarlis, G. P., Stathas, G. J., Sanchís-Segovia, A., Athanassiou, C. G. (2001): The Aphidiinae (Hymenoptera: Ichneumonoidea: Braconidae) of Greece. - Phytoparasitica 29: 306-340.

[21] Kavallieratos, N. G., Tomanović, Ž., Starý, P., Athanassiou, C. G., Sarlis, G. P., Petrović, O., Niketić, M., Veroniki, M. A. (2004): A survey of aphid parasitoids (Hymenoptera: Braconidae: Aphidiinae) of Southeastern Europe and their aphid-plant associations. Applied Entomology \& Zoology 39: 527-563.

[22] Kennedy, J. S., Day, M. F., Eastop, V. F. (1962): A conspectus of aphids as vectors of plant viruses. - Commonwealth Institute of Entomol., London, 114p.

[23] Kiran, E. (1994): Studies on the Types and Natural Enemies of Aphacitic Seeds in Cereal Fields in Southeastern Anatolia Region. $-3^{\text {rd }}$ Reports of the Biological Control Congress, Ankara, pp. 29-37. 
[24] Kök, Ş., Kasap, İ., Özdemir, I. (2016): Aphid (Hemiptera: Aphididae) species determined in Çanakkale Province with a new record for the aphid fauna of Turkey. - Türk. entomol. Derg. 40(4): 397-412. DOI: http://dx.doi.org/10.16970/ted.39399.

[25] Kristoffersen, L. (2003): The chemical ecology of Homoptera from host plants to conspecific interactions. - Department of Ecology Chemical Ecology. Lund University Introductory paper no: 147, 38p.

[26] Legrand, M. A., Colinet, H., Vernon, P., Hance, T. (2004): Autumn, winter and spring dynamics of aphid Sitobion avenae and parasitoid Aphidius rhopalosiphi interactions. Ann. appl. Biol. 145: 139-144.

[27] Magurran, A. E. (2004): Measuring Biological Diversity. - Blackwell Publishing ISBN13: $978-0-632-05633$.

[28] Minks, A. K., Harrewijn, P. (1988): Aphids: Their Biology, Natural Enemies and Control. - World Crop Pests Vol. 2. Elsevier Amsterdam, the Netherlands.

[29] Ölmez, S. (2000): Determination of Aphidoidea (Homoptera) Species and Their Parasitoids and Predators in Diyarbakır Province. - Cukurova University, Graduate School of Natural and Applied Sciences, Master Thesis, Adana, 109p.

[30] Ölmez-Bayhan, S., Bayhan, E., Ozdemir, I. (2012): Survey of predator species of aphids in Batman, Diyarbakir and Mardin provinces of Turkey. - Research on Crops 13(2): 628-633.

[31] Özdemir, I. (2013): Potato aphid vectors of the virus role of diet transplant. - Potato Symposium on Harmful Organisms, 4-7 November, Ankara.

[32] Özdemir, I. (2020): Some new records on aphid (Hemiptera, Aphididae) fauna of Turkey and aphid-host plant interactions. - Journal of the Entomological Research Society 22(2): 191-201.

[33] Petrović, O. (1996): Aphids (Homoptera: Aphididae) on cereal crops. - Review of Research Work at the Faculty of Agriculture 41(2): 159-168.

[34] Praslićka, J., Al-Dobai, S., Huszár, J. (2003): Hymenopteran parasitoids (Hymenoptera: Aphidiidae) of cereal aphids (Sternorrhyncha: Aphidoidea) in winter wheat crops in Slovakia. - Plant Protect. Sci. 39: 97-102.

[35] Remaudière, G., Toros, S., Ozdemir, I. (2006): New contribution to the aphid fauna of Turkey (Hemiptera, Aphidoidea). - Revue Française d'Entomologiae (N.S.) 28(2): 75-96.

[36] Sharkey, M. J., Wharton, R. A. (1997): Morphology and Terminology. - In: Wharton, R. A., Marsh, P. M., Sharkey, M. J. (eds.) Manual of the New World genera of the family. Braconidae (Hymenoptera). ISH, Special Publ. 1. Washington, International Soc. Hymenopterists, pp. 19-37.

[37] Stary, P. (1964): The foci of aphid parasites (Hymenoptera, Aphidiidae) in nature. - Ekol. Polska A 12: 529-554.

[38] Stary, P., Van Harten, A. (1972): A review of the Aphidiidae [Hymenoptera] of Angola. Rev. Cienc. Biol., Univ. Lour. Marques 5(A): 105-120.

[39] Stary, P. (1986): Creeping thistle, Cirsium arvense, as a reservoir of aphid parasitoids (Hymenoptera, Aphidiidae) in agroecosystems. - Acta ent. bohemoslov 83: 425-431.

[40] Şenol, Ö., Akyıldırım, H., Görür, G., Demirtaş, E. (2014): New records for the aphid fauna Hemiptera: Aphidoidea) of Turkey. - Acta Zoologica Bulgarica 66: 133-136.

[41] Şimşek, Z., Aktaş, H., Kondur, Y., Koçak, E., Özdemir, I., Karaca, V. (2005): Using cereal root disease factors for controlling important cereal pest Sunnpest (Eurygaster spp.) in our country. - GAP IV. Agricultural Congress, 21-23 September, ŞANLIURFA/TURKEY.

[42] Tomanović, Ž., Brajković, M., Krunić, M., Stanisavljević, L. (1996): Seasonal dynamics, parasitization and color polymorphism of the pea aphid, Acyrthosiphon pisum (Harris) (Aphididae: Homoptera) on alfalfa in the south part of the Pannonian area. - Tiscia 30: 4558.

[43] Tomanović, Z. (2000): New findings of aphid parasitoids (Hymenoptera: Aphidiidae) from Serbia and Montenegro. - Acta Entomologica Serbica 5(1-2): 111-118.

[44] Tomanović, Z., Brajkovic, M. (2000): Some rare species of aphid parasitoids (Aphidiidae, Hymenoptera) in Yugoslavia. - Protection of Nature 52(1): 65-67. 
[45] Tomanović, Z., Kavallieratos, N. G., Athanassiou, C. G., Petrović, O. (2003): A new Praon species (Hymenoptera: Braconidae: Aphidiinae) of the Uroleucon parasitoid complex from the Mediterranean Area. - Phytoparasitica 31(1): 19-26.

[46] Tuatay, N., Remaudiere, G. (1964): Premiere Contribution au Catalogue des Aphididae (Hom.) de la Turquie. - Rev. Path. Vegveale et D'entomologie Agricole de France 43(4): 243-278.

[47] Tuatay, N. (1988): Aphididae of Turkey: Homoptera: I. Aphidinae: Macrosiphini (Part I). - Plant Protection Bult. 28(1-2): 1-28.

[48] Webster, J. A., Kenkel, P. (1999): Benefits of managing small-grain pests with plant resistance. - In: Iseman, B. R., Webster, J. A. (eds.) Economic, environmental, and social benefits of resistance in field crops. Entomol Soc Am, Lanham, pp. 87-114.

[49] Yüksel, S. (2003): Determination of aphid species (Insecta: Homoptera: Aphidoidea) found in wheat plant in Niğde province and its region. - Niğde University, Institute of Natural and Applied Sciences, Biology Division, Unpublished Master Thesis. 